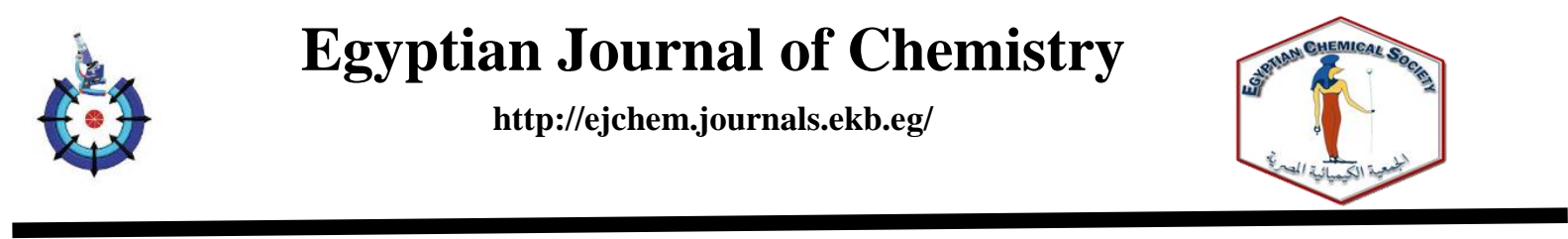

\title{
Effect of Fortification with Sage Loaded Liposome on the Chemical, Physical, Microbiological Properties and Cytotoxicity of Yoghurt
}

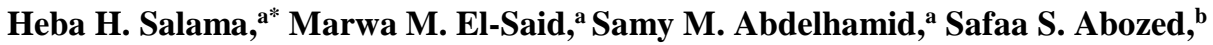

Marwa M. Mounier ${ }^{c}$

${ }^{a}$ Dairy Department, ${ }^{b}$ Department of Food Technology, Food Industry and Nutrition Research Division, ${ }^{c}$ Department of Pharmacognosy, Pharmaceutical and Drug Industries Research Division, National Research Centre, Giza, 33 El-Buhouth St., (former El-Tahrir St.,) Dokki, Giza, Postal Code: 12622, Egypt

\begin{abstract}
The using of plant extract in dairy field is a recent trend to achieve health benefits. Sage (Salvia officinalis $L$ ) is a medicinal plant contained a large number of bioactive and biological compounds. The phenolic compounds, chemical composition and physical properties of sage phenolic extract (SPE) loaded in liposomal system were firstly investigated, and then it was used to fortify yoghurt $(5,10,15$ and $20 \%)$ to produce functional dairy product. Obtained data revealed that the encapsulation efficiency of SPE in liposome was $83.7 \%$, the particle size ranged between 168.30 to $273 \mathrm{~nm}$ and Zeta potential was $+35.4 \mathrm{mV}$. SPE exhibited an inhibition activity against all tested pathogenic bacteria and the antibacterial activity of SPE was increased significantly after encapsulation in liposome. The highest antibacterial activity was noted against $S$. aurous and B. cereus. On another vision; protein, total solids and ash contents of fresh yoghurt increased with increasing the concentration of SPE liposome but decreased after 15 days of storage. The $\mathrm{pH}$ values and diacetyl contents of liposome fortified yoghurt decreased compared to control throughout storage. The acetaldehyde content of control significantly decreased during cold storage while it increased with increasing concentration of SPE liposome in yoghurt. The viscosity of fresh yoghurt increased with the increase of added liposome but decreased after 15 days of storage. Fortification of yoghurt samples with SPE liposome significantly enhanced the viability of L. rhaminosus along the storage period. The high selectivity index values of SPE suggest their safety and cytotoxic selectivity effect on cancer cell.
\end{abstract}

Keywords: Sage; Liposome; Encapsulation efficiency; Yoghurt; Antibacterial activity; Cytotoxic effect.

*Corresponding author e-mail: hebasalama11@yahoo.com; hebasalama11@gmail.com. Receive Date: 06 April 2020, Revise Date: 19 April 2020, Accept Date: 27 April 2020 DOI: 10.21608/EJCHEM.2020.27321.2572

C2020 National Information and Documentation Center (NIDOC) 


\section{Introduction}

Polyphenols are secondary metabolites of plants. These compounds exhibit positive effects on human health. Due to their antioxidant; antimicrobial, anti-inflammatory, anti-osteoporotic and hepatoprotective activity against some chronic diseases such as cancer, type-II diabetes, cardiovascular disease or non-alcoholic fatty liver diseases [1]. Sage (Salvia officinalis $L$ ) is an important medicinal plant, revealed a great number of bioactive compounds and a variety of biological activities. Various studies have shown antioxidant properties, antibacterial, antifungal and anti-inflammatory activity of sage leaves hydroalcoholic and aqueous extracts [2]. However, they are highly unstable prone to degradation by light, oxygen or enzymes. In addition, they may lose their activity by interaction with other food components such as proteins and carbohydrates. So; it might be preserving their properties and protected their activity. Encapsulation is an effective way to protect polyphenols from adverse in conditions, mask their odor and color or inhibit the interaction with other food constituents [3]. As an encapsulation technique, liposome can allow successful delivery of phenolic compounds. Liposome are enclosed spherical vesicles organized by one or several concentric phospholipidic bilayers with an internal aqueous phase which make them a suitable carrier for both water and oil soluble functional compounds. However, the liposome structure is flexible fragile and to overcome this disadvantage their surfaces can be coated with a polymer to ensure their stability. Chitosan, pectin or combined chitosan/pectin coatings can be used as protective coatings for liposome in the acidic milieu of the stomach and triggered release systems in the colon [4].
In another side, yoghurt is one of the important foods to provide the human digestive system with beneficial bacteria strains [5]. Also, it can be employed as a vehicle for bioactive compounds particularly antioxidants in order to improve antioxidant capacity and phenolic in food formulation

In the present study; sage phenolic extract (SPE) was encapsulated in liposome; and the obtained liposome were characterized. The sage loaded liposome were used to fortify yoghurt then, the chemical and physical properties of obtained yoghurt were followed storage of 15 days at $4^{\circ} \mathrm{C}$. Assessment the cytotoxicity of SPE, encapsulated SPE and the fortified yoghurt was carried out on different cancer cell lines.

\section{Materials and Methods}

Dried leaves of sage (moisture $2.87 \%$, ash $6.03 \%$, fat $10.1 \%$, protein $5.84 \%$, fiber $13.65 \%$ and total carbohydrate $61.51 \%$ ) were obtained from a local market in Cairo, Egypt. The dried leaves were powdered using a mortar (total solids $97.13 \%$ ).

Soy lecithin $(69.3 \%$ phosphatidyl choline, $9.8 \%$ phosphatidyl ethanolamine, and $2.1 \%$ lyso phosphatidylcholine) was provided by Lipoid AG (Ludwigshafen, Germany).

Sodium acetate and glacial acetic acid were purchased from Carl Roth GmbH\& Co. KG (Karlsruhe, Germany).

Folin-Ciocalteu reagent, chitosan, Gallic acid and 1,1diphenyl-2-pycrylhydrazyl (DPPH) were purchased from Sigma-Aldrich Co. (St. Louis, USA)

Imported low heat full cream milk powder with $23.6 \%$ protein, $40 \%$ lactose, $28.2 \%$ fat, and $8.2 \%$ ash were obtained from the local market.

Strains of Streptococcus thermophilus, Lactobacillus delbuerkii ssp. bulgaricus, Lactobacillus casei were obtained from stock cultures from the Dairy Microbiology Lab., National Research Centre, Dokki, Cairo, Egypt, and propagated in sterilized reconstituted skimmed milk (10\% w/v) before use. 
Bacillus cereus (ATCC133018), Salmonella typhimurium 9027, Staph aurius (ATCC 25175) obtained from the stock cultures of the Agricultural Research Centre in Giza., E. coli O157:H7 (ATCC 6933) and Listeria monocytogenes V7 and Yersenia enterocolitica subsp. enterocolitica ATCC9610TM were obtained from Liofil chem S.r.l. Italy. Lactobacillus rhamnosus Tistr 541 and Lactobacillus reuteri B-14171 were obtained from Cairo Microbiology Resources Center (Cairo-Mircen, Faculty of Agriculture Ain Shams University).

Colorectal adenocarcinoma (Caco-2 cell line), prostatic carcinoma cell line (PC-3), lung carcinoma (A-549 cell line) and BJ-1 "A telomeraseimmortalized normal foreskin fibroblast cell line was obtained from Karolinska Center, Department of Oncology and Pathology, Karolinska Institute and Hospital, Stockholm, Sweden.

\section{Methods}

Preparation of sage phenolic extract (SPE)

Twenty grams of sage leaves powder was soaked in $120 \mathrm{ml}$ of ethanol $(80 \%)$ for $24 \mathrm{~h}$ at $4{ }^{\circ} \mathrm{C}$, filtered using filter paper (Whatamn No.1) and then evaporated using rotary evaporator. The residual sage phenolic extract was freeze-dried using Lab conco, USA, at -52 EC for $48 \mathrm{~h}$ at a pressure below $0.1 \mathrm{MPa}$, ground to fine powder and kept at $-18^{\circ} \mathrm{C}$ until used. Freeze-dried SPE contained $0.58 \pm 0.01 \mathrm{mg}$ catechin $/ \mathrm{g}$ of phenolics, $0.044 \pm 0.001 \mathrm{mg}$ Rutin/g of flavonoids and exhibited antioxidant capacity of $1.08 \pm 0.004 \mathrm{mmol}$ Trolox $/ \mathrm{g}$ in term of DPPH assay.

\section{Determination of antioxidant capacity}

The DPPH radical-scavenging activity was determined using the method proposed by BrandWilliams et al. [6]. An aliquot $(100 \mu \mathrm{L})$ of the sample solution was mixed with $2.9 \mathrm{~mL}$ of 1,1-diphenyl-2pycrylhydrazyl (DPPH) in methanol. The mixture was shaken vigorously and left to stand for $30 \mathrm{~min}$. Absorbance of the resulting solution was measured at $517 \mathrm{~nm}$ by a UV-visible spectrophotometer. The results were corrected for dilution and expressed as mmol trolox equivalent/g.

\section{Determination of phenolic content}

The method described by Naczk and Shahidi [7] was used for the determination of total phenolic compounds content of SPE extract. Briefly, 0.5-mL of the extract was diluted with $8 \mathrm{~mL}$ distilled water, 0.5 $\mathrm{mL}$ Folin-Ciocalteu's phenol reagent and $1 \mathrm{~mL}$ saturated sodium carbonate solution was added. The mixture was vortexed for $15 \mathrm{Sec}$. left to stand at room temperature for $30 \mathrm{~min}$, and its absorbance was measured at $725 \mathrm{~nm}$ using Spectrophotometer (model 2010, Cecil Instra. Ltd., Cambridge, London). The results are expressed as $\mathrm{mg}$ catechin equivalents per $\mathrm{g}$ of the extract.

\section{Determination of flavonoid content}

Aliquot $(0.5 \mathrm{ml})$ of the sample was mixed with $1.5 \mathrm{~mL}$ of $95 \%$ ethanol, $0.1 \mathrm{~mL}$ of $10 \%$ aluminum chloride, $0.1 \mathrm{~mL}$ of $1 \mathrm{M}$ potassium acetate and $2.8 \mathrm{~mL}$ of distilled water. After incubation at room temperature for $30 \mathrm{~min}$, the absorbance this mixture was measured at $415 \mathrm{~nm}$. The flavonoid content was calculated using a standard calibration of Rutin solution and expressed as mg of Rutin equivalent (RE) per $\mathrm{g}$ of sample [8].

Identification of phenolic and flavonoid compounds in SPE by HPLC

The phenolic and flavonoids components of SPE were separated using HPLC Agilent 1260 series system. The separation was carried out using a C18 column (4.6 $\mathrm{mm} \times 250 \mathrm{~mm}$ i.d., $5 \mu \mathrm{m}$ ). The mobile phase consisted of water: $0.02 \%$ tri-floro-acetic acid in acetonitrile (80:20) at a flow rate $1 \mathrm{ml} / \mathrm{min}$. and the separated components were monitored at $280 \mathrm{~nm}$. The

Egypt. J. Chem. Vol. 63, No.10 (2020) 
injection volume was $10 \mu \mathrm{l}$ for each of the sample solutions. The column temperature was maintained at $35^{\circ} \mathrm{C}$.

Preparation of dispersion liposomal systems with SPE The methods described by El-Messery et al. [9] were used for encapsulation of SPE in liposome. SPE (0.2\% w/v) was added to $2 \%$ lecithin solution in acetate buffer $(0.1 \mathrm{M} \mathrm{pH} 3.5)$. The prepared liposome were added to chitosan solution $(0.8 \%, \mathrm{w} / \mathrm{v})$ in acetate buffer $(\mathrm{pH}=3.5 \pm 0.1 ; 0.1 \mathrm{~mol} / \mathrm{L})$ of the ratio of $1: 1$ (w/w) and stirred over night at room temperature. By this way, negatively charged liposome were coated with positively charged chitosan layer.

\section{Encapsulation Efficiency (EE)}

The dialysis tube diffusion technique was used to determine Encapsulation Efficiency [10]. Aliquot (5 $\mathrm{ml}$ ) of the liposome suspension was placed in the dialysis tube, closed tightly and dialyzed against the acetate buffer $(0.1 \mathrm{M} \mathrm{pH} 3.5)$ at $37^{\circ} \mathrm{C}$ under continues stirring. Samples were taken from the dialysate at successive intervals and assayed, for the release of total phenolic compounds.

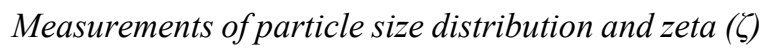
potential

Average particle size (PS), and size distribution (particle dispersity index; PDI) of liposome preparations were measured by dynamic light scattering (Zetasizer var. 704 instruments (Malvern Instruments, Malvern, UK) The sample was suspended and diluted with ultrapure MQ water before measurement it's light scattering for a laser beam (633 $\mathrm{nm})$ at an angle of 173 at $25^{\circ} \mathrm{C}$ over time intervals [11].

\section{Transmission of electron microscope}

Twenty microliters of diluted samples were placed on a film-coated 200-mesh copper specimen grid for 10 min and the excess fluid was removed using filter paper. The grid was then stained with one drop of $3 \%$ phosphor-tungstic acid and allowed to dry for $3 \mathrm{~min}$. The coated grid was dried and examined under the TEM microscope (JEM-2100 Electron Microscope. The samples were observed by operating at $160 \mathrm{kV}$.

\section{Inclusion of SPE liposome into yoghurt formulation}

Full cream milk powder was reconstituted in distilled water $(16 \% \mathrm{w} / \mathrm{v})$. SPE loaded liposome solution was used to replace $5\left(\mathrm{~T}_{1}\right), 10\left(\mathrm{~T}_{2}\right), 15\left(\mathrm{~T}_{3}\right)$ and $20\left(\mathrm{~T}_{4}\right) \%$ of the water used for reconstitution of full cream milk powder. All treatments were heated to $90^{\circ} \mathrm{C}$ for $10 \mathrm{~min}$ and cooled to $42^{\circ} \mathrm{C}$. $2 \%$ Starter cultures $(S$. thermophilus and Lb. delbuerkii ssp. bulgaricus (1:1)) and $2 \%$ probiotic bacteria (L. rhamnosus) were added and poured into cups $(100 \mathrm{ml})$ and incubated at $42^{\circ} \mathrm{C}$ until complete coagulation. All yoghurt cups were stored in a refrigerator $\left(6 \pm^{\circ} \mathrm{C}\right)$ and analyzed when fresh and after 3, 7 and 15 days during storage for 15 days.

\section{Physicochemical analysis of functional yoghurt}

Total solids (T.S), fat, total nitrogen (T.N), ash content and titratable acidity (T.A) were determined according to AOAC [12]. The $\mathrm{pH}$ values were measured using a digital laboratory Jenway 3510 pH meter, UK. Bibby Scientific LTD. Stone, Stafford shire, ST 15 OSA. Diacetyl and acetaldehyde contents were determined according to Less and Jago [13].

\section{Apparent viscosity of functional yoghurt}

Yoghurt samples were gently stirred 5 times clockwise direction with a plastic spoon prior to viscosity measurements. Apparent viscosity was measured at $7^{\circ} \mathrm{C}$ using a Brookfield digital viscometer (Middleboro, MA 02346, U.S.A). The sample was subjected to shear rates ranging from 3 to $100 \mathrm{~S}^{-4}$ for upward curve. Viscosity measurements were 
expressed as centipoise (cP.s) and were performed in triplicate [14].

\section{Antibacterial activity assay}

The antibacterial activity of SPE and SPE- loaded liposome were evaluated by the well diffusion technique according to NCCLS [15]. The test was conducted against six common foodborne pathogenic bacteria namely: Bacillus cereus (ATCC133018), Salmonella typhimurium 9027, Staph aurius (ATCC 25175), E. coli O157:H7 (ATCC 6933), Listeria monocytogenes V7 and Yersenia enterocolitica subsp. enterocolitica ATCC9610TM. Each microorganism was cultured in brain heart infusion broth then spread onto surface of nutrient agar plates with wells $(8 \mathrm{~mm}$ in diameter) full of $70 \mu \mathrm{l}$ of SPE and SPE loaded liposome. After incubation for $24 \mathrm{~h}$ at $37^{\circ} \mathrm{C}$, all plates were examined for the diameter of the inhibition zone. The experiment was repeated two times, and the results ( $\mathrm{mm}$ diameter of inhibition zone) were expressed as average values.

\section{Evaluation of Prebiotic activity}

The prebiotic activities of SPE and SPE loaded liposome were investigated on the growth of Lactobacillus casei, Lactobacillus rhamnosus Tistr 541 and Lactobacillus reuteri B-14171 previously activated by inoculating in de Man-Rogasa-Sharpe (MRS) broth and incubating at $37^{\circ} \mathrm{C}$ for $24 \mathrm{~h}$. The probiotic biomass in late-log phase was harvested by centrifugation at $6000 \mathrm{~g}$ for $10 \mathrm{~min}$ at $4{ }^{\circ} \mathrm{C}$ (Sorvall, model RC-5C, rotor GS3, Newtown, CT), and washed twice in sterile saline solution. Then $\sim 10^{3} \mathrm{CFU} \mathrm{ml}^{-1}$ of bacterial suspension was inoculated into $20 \mathrm{ml}$ of fresh MRS broth containing of SPE and SPE loaded liposome and incubated at $37^{\circ} \mathrm{C}$ for $48 \mathrm{~h}$. The bacterial growth was monitored at $6,12,24$ and $48 \mathrm{~h}$ by preparing 10-fold serial dilutions and spreading $100 \mu \mathrm{l}$ aliquot on the surface of MRS agar plates. The plates were incubated at $37^{\circ} \mathrm{C}$ for $48 \mathrm{~h}$. Bacterial count was calculated through enumerating the colony numbers on the plates [16].

\section{Microbiological analysis of yoghurt}

All yoghurt samples (control and treatments) were microbiologically examined after $0,3,7$ and 15 days of cold storage period. Total aerobic colony count (TACC), mold and yeast, and coliform bacteria were enumerated using the selective media and the conventional methods according to FDA [17] Streptococcus thermophilus was enumerated on M17 agar after aerobic incubation at $37^{\circ} \mathrm{C}$ for $48 \mathrm{~h}$. Lactobacillus bulgaricus and Lactobacillus rhamnosus were enumerated using modified MRS agar supplemented with $0.05 \%$ L-cysteine- $\mathrm{HCl}$ and the plates were incubated at $37^{\circ} \mathrm{C}$ for $48 \mathrm{~h} \mathrm{[16]}$

\section{Cancer cell viability assay (CCVA)}

The CCVA was assayed according to Batran et al. [18], the cells were seeded at concentration of $10 \times 10^{3}$ cells per well in case of PC $3,20 \times 10^{3}$ cells/well in case of A-549 and Caco- 2 cell lines and $40 \times 10^{3}$ cells/well in a fresh complete growth medium in case of BJ-1 using 96-well microtiter plastic plates at $37^{\circ} \mathrm{C}$ for 24 hours under $5 \% \mathrm{CO}_{2}$, in a water jacketed carbon dioxide incubator. After 48 hours' incubation, the medium was aspirated and then MTT salt were added to each well and incubated for further four hours at $37^{\circ} \mathrm{C}$ under $5 \% \quad \mathrm{CO}_{2}$. To stop the reaction and dissolving the formed crystals, $10 \%$ sodium dodecyl sulphate (SDS) solution was added to each well and incubated overnight at $37^{\circ} \mathrm{C}$. The absorbance was measured using a microplate multi-well reader at $595 \mathrm{~nm}$ and a reference wavelength of $690 \mathrm{~nm}$. Cell viability was assessed according to the mitochondrialdependent reduction of yellow MTT (3-(4, 5dimethylthiazol-2-yl)-2, 5-diphenyl tetrazolium bromide) to purple formazan. 


\section{Statistical analyses}

All data were expressed as the mean of triplicate determinations. Statistical analysis was carried out using SPSS for Windows, Version Rel. 10.0.5., Inc. $\mathrm{p}<0.05$ were considered to be significant.

\section{Results and Discussion}

Phenolic profile of SPE

The phenolic profile $(\mathrm{mg} / \mathrm{g})$ of SPE obtained after ethanol/water extraction is shown in Fig. 1, while concentration of the identified compounds is given in Table 1 fourteen compounds were detected. Eight of which were phenolic acid derivatives and six flavonoids.

Table 1. Phenolic profile $(\mathrm{mg} / \mathrm{g})$ of SPE

\begin{tabular}{lc}
\hline Phenolic compounds (PC) & $\begin{array}{c}\text { Concentration of } \\
\text { PC }(\mathrm{mg} / \mathrm{g})\end{array}$ \\
\hline Gallic acid & 4.58 \\
Chlorogenic acid & 3.84 \\
Catechin & 2.26 \\
Coffeic acid & 1.12 \\
Syringic acid & 0.08 \\
Rutin & 0.00 \\
Ellagic acid & 0.16 \\
Coumaric acid & 2.41 \\
Vanillin & 1.69 \\
Ferulic acid & 0.57 \\
Naringenin & 0.32 \\
Propyl Gallate & 0.012 \\
Querectin & 0.76 \\
Cinnamic acid & 0.094 \\
\hline
\end{tabular}

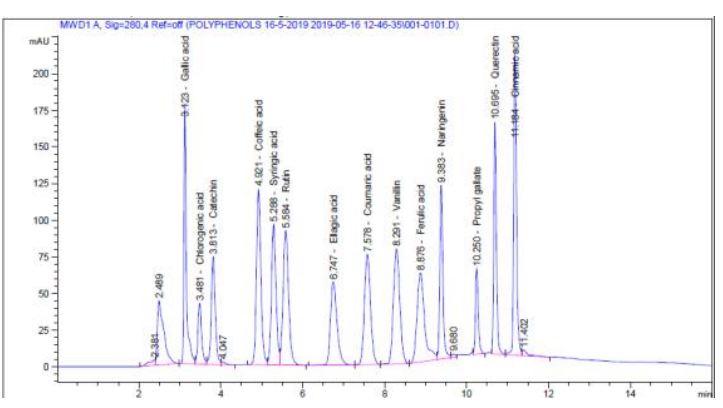

Fig.1. Phenolic profile (mg/g) of SPE

\section{Characterizations of SPE loaded liposome}

By definition, encapsulation efficiency is the amount of core material encapsulated inside the particles.
Encapsulation efficiency of SPE loaded liposome was found to be $83.7 \%$. In other words, about $83 \%$ of the added SPE were entrapped within the liposome and less than $17 \%$ has been remained un-encapsulated. It is generally accepted that the encapsulation efficiency of the active substances within liposomal structure can be affected by the size and/or specific surface areas of the liposome [19]. Previous studies which reported high yields (83-95\%) of nanoliposome [9] to agreement with the present results by El-Said et al. [10]. Fig. 2 shows the morphology of SPE loaded liposome. Zeta potential of SPE loaded liposome was $+35.4 \mathrm{mV}$ since negatively charged of SPE enhanced the positively charge of liposome. The particle size of SPE loaded liposome ranged between 168.30 to 273 $\mathrm{nm}$

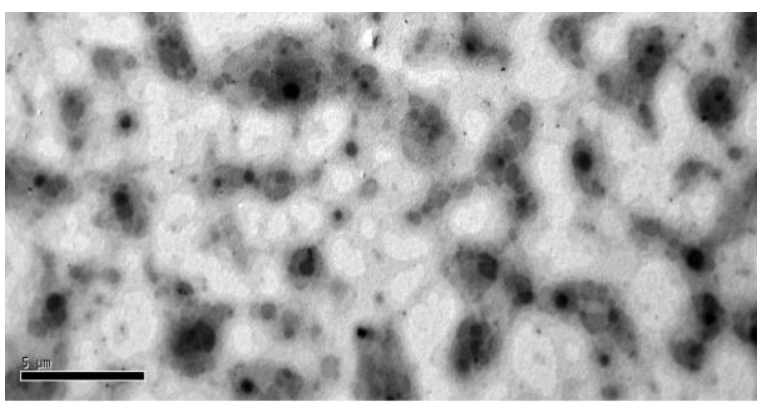

Fig. 2. Micrograph of SPE loaded liposome

\section{Chemical composition of functional yoghurt}

Data presented in Table 2 showed that the mean of moisture content decreased slightly by increasing concentration of SPE loaded liposome $\left(T_{1}>T_{2}>T_{3}>T_{4}\right)$ also during storage compare to control samples. The mean values of total solids slightly increased by increasing concentration of SPE liposome $\left(\mathrm{T}_{4}>\mathrm{T}_{3}>\mathrm{T}_{2}>\mathrm{T}_{1}\right)$ also during the storage period. This may be due to including lecithin as an emulsifier in liposome preparation that could increase total solids [20]. Protein and ash contents increased significantly with increasing concentration of SPE loaded liposome at fresh while the values significantly decreased after 15 days of storage. The $\mathrm{pH}$ values of yoghurt from

Egypt. J. Chem. 63, No. 10 (2020) 
different treatments decreased in descending order $\left(\mathrm{T}_{4}>\mathrm{T}_{3}>\mathrm{T}_{2}>\mathrm{T}_{1}\right)$ compared to control in fresh and after 15 days of storage, which was probably due to the production of lactic acid by starter culture and probiotic bacteria [21]. Generally, the functional yoghurt with SPE loaded liposome exhibited lower $\mathrm{pH}$ and higher acidity after 15 days of storage than the control yoghurt, the results are in the line with Zhong et al. [21]. The $\mathrm{pH}$ and acidity results reflect the enhanced activity of starter and probiotic bacteria [22] After 15 days of cold storage; diacetyl recorded highest value in all treatment compared to control.

Acetaldehyde values of control sample decreased significantly during cold storage while it increased with increasing the added percentage of SPE loaded liposome in yoghurt but decreased during storage. This may be due to the variable ability lactic acid bacteria to lowest acetaldehyde to ethanol. The same

Table 2. Chemical composition of yoghurt supplemented with SPE liposome

\begin{tabular}{|c|c|c|c|c|c|c|c|c|c|}
\hline $\begin{array}{l}\text { Treat } \\
\text { ments }\end{array}$ & $\begin{array}{c}\text { Stor } \\
\text { age } \\
\text { Day } \\
\text { s } \\
\end{array}$ & $\begin{array}{c}\text { Total } \\
\text { solids } \%\end{array}$ & Fat $\%$ & $\begin{array}{c}\text { Protein } \\
\%\end{array}$ & Ash\% & pH & $\begin{array}{c}\text { Acidity } \\
\%\end{array}$ & $\begin{array}{c}\text { Diacetyl } \\
(\boldsymbol{\mu m} / \mathbf{1 0 0} \\
\mathrm{g})\end{array}$ & $\begin{array}{c}\text { Acetalde } \\
\text { hyde } \\
(\mu \mathrm{m} / \mathbf{1 0 0} \\
\mathrm{g})\end{array}$ \\
\hline \multirow{2}{*}{ Control } & & $14.21^{\mathrm{e}}$ & $4.00^{\mathrm{a}}$ & $3.50^{\mathrm{b}}$ & $0.56^{c}$ & $4.69^{d}$ & $0.95^{\mathrm{a}}$ & $33.60^{\mathrm{e}}$ & $13.28^{\mathrm{e}}$ \\
\hline & & \pm 0.01 & \pm 0.10 & \pm 0.20 & \pm 0.03 & \pm 0.03 & \pm 0.04 & \pm 1.63 & \pm 0.05 \\
\hline \multirow{2}{*}{$\mathbf{T}_{1}$} & & $14.44^{\mathrm{d}}$ & $4.00^{\mathrm{a}}$ & $3.55^{\mathrm{b}}$ & $0.67^{\mathrm{b}}$ & $4.72^{\mathrm{d}} \pm$ & $0.91^{\mathrm{ab}}$ & $114.40^{\mathrm{d}}$ & $14.78^{\mathrm{d}}$ \\
\hline & & \pm 0.13 & \pm 0.30 & \pm 0.25 & \pm 0.03 & 0.01 & \pm 0.14 & \pm 3.10 & \pm 0.22 \\
\hline \multirow{2}{*}{$\mathbf{T}_{2}$} & 7 & $14.58^{\mathrm{c}}$ & $4.00^{\mathrm{a}}$ & $3.58^{b}$ & $0.75^{\mathrm{b}}$ & $4.83^{c}$ & $0.89^{b c}$ & $162.40^{c}$ & $19.78^{c}$ \\
\hline & $\stackrel{8}{2}$ & \pm 0.03 & \pm 0.20 & \pm 0.04 & \pm 0.09 & \pm 0.02 & \pm 0.01 & \pm 0.53 & \pm 0.22 \\
\hline \multirow{2}{*}{$\mathbf{T}_{3}$} & & $14.71^{\mathrm{b}}$ & $4.00^{\mathrm{a}}$ & $3.90^{\mathrm{b}}$ & $0.87^{\mathrm{a}}$ & $4.88^{b}$ & $0.85^{\mathrm{cd}}$ & $194.00^{\mathrm{b}}$ & $22.32^{\mathrm{b}}$ \\
\hline & & \pm 0.31 & \pm 0.10 & \pm 0.40 & \pm 0.03 & \pm 0.01 & \pm 0.03 & \pm 2.0 & \pm 0.68 \\
\hline \multirow{2}{*}{$\mathbf{T}_{4}$} & & $14.90^{\mathrm{a}}$ & $4.00^{\mathrm{a}}$ & $4.09^{\mathrm{ab}}$ & $0.94^{\mathrm{a}}$ & $4.99^{\mathrm{a}}$ & $0.82^{\mathrm{d}}$ & $209.20^{\mathrm{a}}$ & $24.36^{\mathrm{a}} \pm$ \\
\hline & & \pm 0.15 & \pm 0.30 & \pm 0.09 & \pm 0.05 & \pm 0.01 & \pm 0.01 & \pm 1.08 & 1.36 \\
\hline \multirow{2}{*}{ Control } & & $15.06^{\mathrm{c}}$ & $4.20^{\mathrm{a}}$ & $3.46^{c}$ & $0.51^{\mathrm{d}}$ & $4.34^{\mathrm{c}}$ & $1.77^{\mathrm{a}}$ & $79.20^{\mathrm{e}}$ & $9.56^{c} \pm$ \\
\hline & & \pm 0.12 & \pm 0.30 & \pm 0.04 & \pm 0.04 & \pm 0.04 & \pm 0.06 & \pm 0.80 & 0.19 \\
\hline \multirow{2}{*}{$\mathbf{T}_{1}$} & & $15.35^{\mathrm{bc}}$ & $4.20^{\mathrm{a}}$ & $3.52^{c}$ & $0.64^{c}$ & $4.38^{c}$ & $1.74^{\mathrm{a}}$ & $147.20^{\mathrm{d}}$ & $12.40^{\mathrm{b}} \pm$ \\
\hline & & \pm 0.24 & \pm 0.36 & \pm 0.08 & \pm 0.06 & \pm 0.04 & \pm 0.03 & \pm 0.80 & 0.4 \\
\hline \multirow{2}{*}{$\mathbf{T}_{2}$} & 15 & $15.40^{\mathrm{ab}}$ & $4.20^{\mathrm{a}}$ & $3.54^{\mathrm{c}}$ & $0.73^{b}$ & $4.54^{\mathrm{b}}$ & $1.72^{\mathrm{a}}$ & $250.40^{c}$ & $12.48^{\mathrm{b}} \pm$ \\
\hline & 15 & \pm 0.17 & \pm 0.17 & \pm 0.06 & \pm 0.03 & \pm 0.12 & \pm 0.04 & \pm 6.95 & 0.31 \\
\hline \multirow{2}{*}{$\mathbf{T}_{3}$} & & $15.84^{\mathrm{a}}$ & $4.20^{\mathrm{a}}$ & $3.78^{\mathrm{b}}$ & $0.85^{\mathrm{a}}$ & $4.67^{\mathrm{a}}$ & $1.47^{\mathrm{b}}$ & $320.40^{\mathrm{b}}$ & $18.60^{\mathrm{a}}$ \\
\hline & & \pm 0.11 & \pm 0.26 & \pm 0.04 & \pm 0.03 & \pm 0.03 & \pm 0.02 & \pm 3.40 & \pm 0.02 \\
\hline \multirow{2}{*}{$\mathbf{T}_{4}$} & & $15.87^{\mathrm{a}}$ & $4.20^{\mathrm{a}}$ & $3.98^{\mathrm{a}}$ & $0.91^{\mathrm{a}}$ & $4.69^{\mathrm{a}}$ & $1.41^{\mathrm{b}}$ & $396.80^{\mathrm{a}}$ & $19.01^{\mathrm{a}} \pm$ \\
\hline & & \pm 0.21 & \pm 0.17 & \pm 0.02 & \pm 0.04 & \pm 0.05 & \pm 0.11 & \pm 0.80 & 0.16 \\
\hline
\end{tabular}

Control: yoghurt without sage phenols extract (SPE) liposome, T1: yoghurt with 5\% SPE liposome, T2: yoghurt with 10\% SPE liposome, T3: yoghurt with $15 \%$ SPE liposome, T4: yoghurt with $20 \%$ SPE Liposome. The means with the different capital (A, B, C...) superscript letters within the same column indicate significant $(\mathrm{P} \leq 0.05)$ differences between treatment

growth and activity of yoghurt starter and probiotic

bacteria as confirmed by microbiological evaluation

(Table 6). Development of acidity during storage was more pronounced to control yoghurt compared to yoghurt fortified with SPE loaded liposome. This suggest that the added liposome affected the growth and acidity of the used starter and probiotic organisms [24].

Diacetyl values increased by increasing percentage of added loaded SPE loaded liposome in yoghurt compared to control. These results may be due to the was reported by Abd El-Aziz et al. [23] who recorded a positive relation between acidity and diacetyl contents.

\section{Phenolic content (PC) of yoghurt}

Table 3 shows that the addition of SPE loaded liposome to milk prior to yoghurt manufacture increased significantly $(p<0.05)$ the PC content of yoghurt. During storage, the PC content in yoghurt increased steadily with SPE loaded liposome during storage to reach at least 3 times its content than control 
Table 3. Phenolic compounds content (mg catechin equivalent/g) in yoghurt samples during storage period.

\begin{tabular}{cccc}
\hline Treatments* & Fresh & Storage period (day) & $\mathbf{1 5}$ \\
\hline Control $_{\mathbf{T}_{\mathbf{1}}}$ & $0.360 \pm 0.042$ & $0.305 \pm 0.005$ & $0.268 \pm 0.009$ \\
$\mathbf{T}_{\mathbf{2}}$ & $0.520 \pm 0.014$ & $0.514 \pm 0.004$ & $0.506 \pm 0.005$ \\
$\mathbf{T}_{\mathbf{3}}$ & $0.730 \pm 0.025$ & $0.713 \pm 0.012$ & $0.694 \pm 0.005$ \\
$\mathbf{T}_{\mathbf{4}}$ & $0.944 \pm 0.013$ & $0.916 \pm 0.007$ & $0.899 \pm 0.004$ \\
\hline
\end{tabular}

*See footnote table (2)

at the end of storage period. Similar results were reported in previous studies [9,10]. During storage,

PC content of treated yoghurt $\left(\mathrm{T}_{1}, \mathrm{~T}_{2}\right.$ and $\left.\mathrm{T}_{3}\right)$ were decreased but still high than control sample. This can be explained by the binding of polyphenols to milk proteins.

\section{Viscosity of yoghurt}

Fig. 3, 4 show that the apparent viscosity of yoghurt increased dramatically with increased addition of SPE loaded liposome compared to the control. The significant increase in apparent viscosity of fresh samples may be due to absorption of water by lecithin used to the preparation of liposome which would increase the viscosity [20], also, the increase of the total solids in yoghurt with added liposome (Table 1) may also be responsible for the increased viscosity. After 15 days of storage, the viscosity of control yoghurt and yoghurt with added liposome decreased which may be due to protein degradation. Several researchers reported that yoghurt is a thixotropic fluid, so viscosity measurements showed the thixotropic characteristics of yoghurt samples which showed a reduction of viscosity in time, in accordance with the

Table 4. Antimicrobial activity of SPE and its liposome

data presented in the literature as confirmed by Dabija et al. [24].
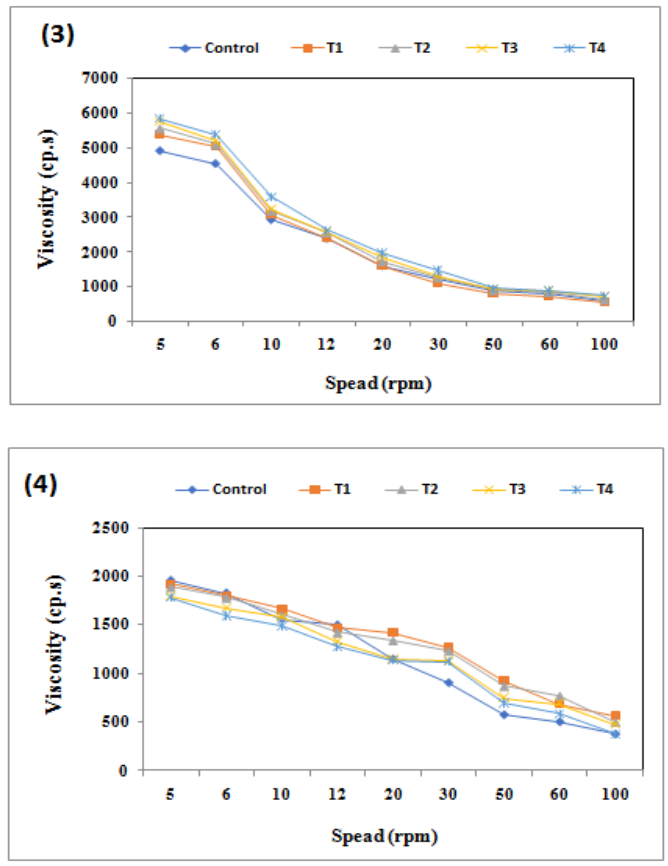

Fig. 3,4 Effect of SPE loaded liposome on the viscosity of yoghurt samples fresh (3) and after 15 days (4) of cold storage.

The antibacterial activity of SPE and SPE loaded liposome

The antibacterial activity of SPE and SPE loaded liposome against six pathogenic bacteria are shown in

Table. 4. SPE inhibited variably all tested bacteria where the highest inhibition zone was for $S$. aurous $(16.0 \mathrm{~mm})$ while Salmonella typhimurium was the

\begin{tabular}{|c|c|c|c|c|c|c|}
\hline \multirow[b]{2}{*}{ Treatments } & \multicolumn{6}{|c|}{ Diameter of inhibition zone (mm) } \\
\hline & $\begin{array}{c}\text { E. coli } \\
\text { O157:H7 }\end{array}$ & $\begin{array}{c}\text { Yersinia } \\
\text { enterocolitica } \\
\text { ATCC } 9610\end{array}$ & $\begin{array}{c}\text { Salmonel } \\
\text { la ATCC } \\
9027\end{array}$ & $\begin{array}{c}\text { Listeria } \\
\text { monocytog } \\
\text { enes V7 }\end{array}$ & $\begin{array}{c}\text { Staph. } \\
\text { aurous } \\
\text { ATCC } \\
25175\end{array}$ & $\begin{array}{c}\text { Bacillus cereus } \\
\text { ATCC } 33018\end{array}$ \\
\hline SPE & $5.3^{\mathrm{Bd}}$ & $5.0^{\mathrm{Bd}}$ & $4.3^{\mathrm{Be}}$ & $8.5^{\mathrm{Bc}}$ & $16.0^{\mathrm{Ba}}$ & $9.2^{\mathrm{Bb}}$ \\
\hline SPE liposome & $15.5^{\mathrm{Ae}}$ & $20^{\mathrm{Ab}}$ & $16.1^{\mathrm{Ad}}$ & $19.1^{\mathrm{Aac}}$ & $27.1^{\mathrm{Aa}}$ & $21.3^{\mathrm{Ab}}$ \\
\hline
\end{tabular}

The means with the different capital (A, B, C...) superscript letters within the same column indicate significant (P $\leq 0.05)$ differences between treatments. Means with the different small $(\mathrm{a}, \mathrm{b}, \mathrm{c}$,$) superscript letters within the same row are significantly (\mathrm{P} \leq 0.05)$ different between treatment

Egypt. J. Chem. 63, No. 10 (2020) 
least sensitive strain. Antibacterial activity of SPE was significantly increased after encapsulation and the strongest antibacterial activity was seen against $S$. aurous and B. cereus with inhibition zones of 27.1 and $21.3 \mathrm{~mm}$ respectively. This may be due to the interaction between SPE liposome and bacterial cells through various ways including inter membrane transfer, contact release, absorption, fusion and phagocytosis [25].

Recently Cantor et al. [26] reported that after coating the liposome with Eudragit E-100 (cationic polymer) antibacterial activity increased approximately 12.5 times and these vehicles would protect the entrapped peptides from degradation by bacterial proteases.

\section{Growth of yoghurt starter and probiotics in media}

The $L A B$ count in culture media containing SPE and SPE loaded liposome are shown in Table 5. In control group, no significant changes were found in bacterial count during the first six hours. Afterward, the growth significantly enhanced, up to $24 \mathrm{~h}$ whereas the count reached a maximum and remained constant up to $48 \mathrm{~h}$. Addition of both SPE and SPE loaded liposome improved the growth of probiotic Lactobacilli, Behradmanesh et al. [27] found growth of L. casei, L. rhaminosus and L. reuteri in medium containing SPE generally showed similar trend in control. The addition of SPE loaded liposome enhanced significantly the growth rate of $L$. rhaminosus after $24 \mathrm{~h}$ and $48 \mathrm{~h}$, since the bacterial number was 1.0 and $0.95 \log$ higher than control, respectively. This may be improved ingredient bioavailability and enhanced the antioxidant activity [28]. Also, addition of SPE significantly increased growth rate of $L$. casei and $L$. reuteri in all interval times compared to the control group and these results agree with Shori and Albloushi [29] who found the SPE to enhance the growth of the Lactobacillus plantarum in yoghurt.

Microbiological quality of yoghurt

Data presented in Table 6 show that, the counts of Lb. delbrueckii ssp. bulgaricus and Str. thermophilus were higher in control sample than yoghurt treated at $1^{\text {st }}$ day of storage then yoghurt cultures were slightly decreased for all samples during storage. Similar findings were obtained by El Batawy [30] who recorded decreases in the growth of yoghurt cultures during cold storage period. Also, the current study revealed a gradual decrease in the viability of probiotic strains (L. rhaminosus) in yoghurt during the cold storage period that could be due to the sensitively of this bacterial strain to acid development that was in consistent [31]. On the other hand, fortification of yoghurt with SPE loaded liposome enhanced significantly the viability of $L$. rhaminosus probiotic strain along the storage period that was in line with Bisar et al. [31]. In general, the food industry has targeted bacterial populations over $10^{6}$ probiotics/g at the time of consumption of strain added to food [32]. Moreover, yeast and mold could be observed and counted after 7 days of the storage in control and after 14 days in treated yoghurt samples $\left(\mathrm{T}_{2}\right.$ and $\left.\mathrm{T}_{3}\right)$ and this in line with El Batawy et al. [30], while yoghurt samples were free from coliform bacteria.

Table 5. Effect of SPE and SPE loaded liposome on growth of Lactic acid bacteria (log cfu/g)

\begin{tabular}{ccccccccccccc}
\hline \multirow{2}{*}{ Treatments } & \multicolumn{4}{c}{ L. casei } & \multicolumn{4}{c}{ L. rhamnosus } & \multicolumn{4}{c}{ L. reuteri } \\
& $6 \mathrm{~h}$ & $12 \mathrm{~h}$ & $24 \mathrm{~h}$ & $48 \mathrm{~h}$ & $6 \mathrm{~h}$ & $12 \mathrm{~h}$ & $24 \mathrm{~h}$ & $48 \mathrm{~h}$ & $6 \mathrm{~h}$ & $12 \mathrm{~h}$ & $24 \mathrm{~h}$ & $48 \mathrm{~h}$ \\
\hline Control & $8.1^{\mathrm{B}}$ & $8.6^{\mathrm{B}}$ & $8.8^{\mathrm{C}}$ & $8.9^{\mathrm{C}}$ & $8.0^{\mathrm{B}}$ & $8.2^{\mathrm{C}}$ & $8.9^{\mathrm{C}}$ & $9.0^{\mathrm{B}}$ & $8.18^{\mathrm{A}}$ & $8.32^{\mathrm{A}}$ & $8.61^{\mathrm{B}}$ & $8.71^{\mathrm{A}}$ \\
SPE & $8.35^{\mathrm{A}}$ & $8.85^{\mathrm{A}}$ & $9.1^{\mathrm{B}}$ & $9.3^{\mathrm{B}}$ & $8.6^{\mathrm{A}}$ & $8.8^{\mathrm{A}}$ & $9.1^{\mathrm{B}}$ & $9.2^{\mathrm{B}}$ & $8.1^{\mathrm{A}}$ & $8.3^{\mathrm{A}}$ & $8.7^{\mathrm{A}}$ & $8.76^{\mathrm{A}}$ \\
SPE loaded liposome & $7.45^{\mathrm{C}}$ & $8.5^{\mathrm{B}}$ & $9.4^{\mathrm{A}}$ & $9.7^{\mathrm{A}}$ & $7.7^{\mathrm{C}}$ & $8.6^{\mathrm{B}}$ & $9.9^{\mathrm{A}}$ & $9.95^{\mathrm{A}}$ & $7.71^{\mathrm{C}}$ & $8.0^{\mathrm{B}}$ & $8.8^{\mathrm{A}}$ & $8.85^{\mathrm{A}}$ \\
\hline
\end{tabular}

The means with the different capital (A, B, C...) superscript letters within the same column indicate significant (P $\leq 0.05)$ differences between treatments

Egypt. J. Chem. Vol. 63, No.10 (2020) 
Table 6. Microbiological analysis of yoghurt fortified with SPE liposome during storage

\begin{tabular}{|c|c|c|c|c|}
\hline \multirow[t]{3}{*}{ Treatments* } & \multicolumn{4}{|c|}{ Counts $(\log$ cfu/ml) } \\
\hline & Fresh & 3 & & 15 \\
\hline & \multicolumn{4}{|c|}{ Lb. delbrueckii ssp. bulgaricus } \\
\hline Control & $7.90^{\mathrm{A}}$ & $7.0^{\mathrm{C}}$ & $6.81^{\mathrm{B}}$ & $6.18^{\mathrm{D}}$ \\
\hline $\mathbf{T}_{1}$ & $7.11^{\mathrm{E}}$ & $6.98^{\mathrm{C}}$ & $6.51^{\mathrm{C}}$ & $6.01^{\mathrm{E}}$ \\
\hline $\mathbf{T}_{2}$ & $7.2^{\mathrm{D}}$ & $7.1^{\mathrm{B}}$ & $6.81^{\mathrm{B}}$ & $6.5^{\mathrm{C}}$ \\
\hline $\mathbf{T}_{3}$ & $7.28^{\mathrm{C}}$ & $7.11^{\mathrm{B}}$ & $6.85^{\mathrm{B}}$ & $6.62^{\mathrm{B}}$ \\
\hline $\mathbf{T}_{4}$ & $7.31^{\mathrm{B}}$ & $7.21^{\mathrm{A}}$ & $7.1^{\mathrm{A}}$ & $6.78^{\mathrm{A}}$ \\
\hline \multicolumn{5}{|c|}{ Str. thermophilus } \\
\hline Control & $8.1^{\mathrm{A}}$ & $7.77^{\mathrm{A}}$ & $7.12^{\mathrm{D}}$ & $6.23^{\mathrm{C}}$ \\
\hline $\mathbf{T}_{1}$ & $7.8^{\mathrm{B}}$ & $7.71^{\mathrm{AB}}$ & $7.30^{\mathrm{C}}$ & $6.80^{\mathrm{B}}$ \\
\hline $\mathbf{T}_{2}$ & $7.81^{\mathrm{B}}$ & $7.75^{\mathrm{B}}$ & $7.41^{\mathrm{B}}$ & $6.91^{\mathrm{A}}$ \\
\hline $\mathbf{T}_{3}$ & $7.95^{\mathrm{A}}$ & $7.80^{\mathrm{AB}}$ & $7.51^{\mathrm{A}}$ & $6.95^{\mathrm{A}}$ \\
\hline $\mathbf{T}_{4}$ & $8.1^{\mathrm{A}}$ & $7.95^{\mathrm{A}}$ & $7.60^{\mathrm{A}}$ & $7.00^{\mathrm{A}}$ \\
\hline \multicolumn{5}{|c|}{ L. rhamnosus } \\
\hline \multicolumn{5}{|l|}{ Control } \\
\hline $\mathbf{T}_{1}$ & $7.18^{\mathrm{C}}$ & $7.65^{\mathrm{B}}$ & $7.40^{\mathrm{D}}$ & $6.55^{\mathrm{D}}$ \\
\hline $\mathbf{T}_{2}$ & $7.25^{\mathrm{C}}$ & $7.86^{\mathrm{A}}$ & $7.55^{\mathrm{C}}$ & $6.78^{\mathrm{C}}$ \\
\hline $\mathbf{T}_{3}$ & $7.38^{\mathrm{B}}$ & $7.98^{\mathrm{A}}$ & $7.71^{\mathrm{B}}$ & $6.88^{\mathrm{B}}$ \\
\hline $\mathbf{T}_{4}$ & $7.61^{\mathrm{A}}$ & $7.56^{\mathrm{C}}$ & 7. $80^{\mathrm{A}}$ & $6.98^{\mathrm{A}}$ \\
\hline \multicolumn{5}{|c|}{ Total bacteria count } \\
\hline Control & $8.18^{\mathrm{C}}$ & $8.2^{\mathrm{C}}$ & $8.0^{\mathrm{C}}$ & $7.95^{\mathrm{C}}$ \\
\hline $\mathbf{T}_{1}$ & $8.12^{\mathrm{C}}$ & $8.23^{\mathrm{C}}$ & $8.25^{\mathrm{B}}$ & $8.10^{\mathrm{B}}$ \\
\hline $\mathbf{T}_{2}$ & $7.95^{\mathrm{D}}$ & $8.11^{\mathrm{D}}$ & $8.30^{\mathrm{B}}$ & $8.11^{\mathrm{B}}$ \\
\hline $\mathbf{T}_{\mathbf{3}}$ & $8.65^{\mathrm{A}}$ & $8.71^{\mathrm{A}}$ & $8.61^{\mathrm{A}}$ & $8.21^{\mathrm{AB}}$ \\
\hline $\mathbf{T}_{4}$ & $8.5^{\mathrm{B}}$ & $8.65^{\mathrm{B}}$ & $8.51^{\mathrm{A}}$ & $8.30^{\mathrm{A}}$ \\
\hline \multicolumn{5}{|c|}{ Yeast and mold } \\
\hline Control & ND & ND & $2.3^{\mathrm{A}}$ & $3.1^{\mathrm{A}}$ \\
\hline $\mathbf{T}_{1}$ & ND & ND & $2.0^{\mathrm{B}}$ & $2.5^{\mathrm{B}}$ \\
\hline $\mathbf{T}_{2}$ & ND & ND & $2.0^{\mathrm{B}}$ & $2.0^{\mathrm{C}}$ \\
\hline $\mathbf{T}_{3}$ & ND & ND & ND & $2.0^{\mathrm{C}}$ \\
\hline $\mathbf{T}_{4}$ & ND & ND & ND & ND \\
\hline
\end{tabular}

*See footnote table (2). The means with the different capital (A, B, C...) superscript letters within the same column indicates significant $(\mathrm{P} \leq 0.05)$ differences between treatments.

Cytotoxic activity effect of SPE, SPE liposome and yoghurt fortified with SPE liposome using different types of cell lines

According to the results in Table 7 and 8, SPE possessed high cytotoxic activity over colon and prostate cancer cells. Also, SPE liposome assayed for their cytotoxic potentiality, the results imply the activity of the SPE with moderate activity on colon cancer cells and weak activity on prostate cells, while SPE liposome alone were examined its effect on cancer cells as well, to confirm the responsibility of the powder of their anticancer activity. SPE was further assayed in a dose-dependent manner at 4 different concentrations ranged from from100-12.5 $\mathrm{ug} / \mathrm{ml}$ to calculate IC 50 and SI. SPE liposome showed IC50 23.1 \pm 0.3 on $\mathrm{CaCo} 2$ with SI 2.1, while SPE had IC50 $5.5 \pm 0.5$ on PC3 with SI value 8.7. The high selectivity index values of SPE suggest their safety

Table 7. In vitro cytotoxicity of samples, against human colon tumor (CaCo2), lung tumor (A-549) cell lines and human prostate tumor (PC3) at concentration and human normal skin fibroblast $100 \mathrm{ug} / \mathrm{ml} *$

\begin{tabular}{ccccc}
\hline Treatments & caco2 & A-549 & Pc3 & BJ-1 \\
\hline SPE & 96.9 & 12.1 & 88.8 & 66.5 \\
SPE liposome & 60.8 & ND & 27.9 & 7.1 \\
liposome (without SPE) & 3.7 & ND & 11.7 & 0 \\
\hline
\end{tabular}

Egypt. J. Chem. 63, No. 10 (2020) 
Table 8. In vitro cytotoxicity percent of samples, against human colon tumor (CaCo2) and human prostate tumor $(\mathrm{PC} 3)$ at concentration $100 \mathrm{ug} / \mathrm{ml}^{*}$

\begin{tabular}{ccc}
\hline Treatments* $^{*}$ & PC3 & caco2 \\
\hline Control & 71.5 & 47.5 \\
$\mathrm{~T}_{1}$ & 53.9 & 44.2 \\
$\mathrm{~T}_{2}$ & 82.3 & 49.0 \\
$\mathrm{~T}_{3}$ & 53.1 & 45.4 \\
$\mathrm{~T}_{4}$ & 42.1 & 47.4 \\
\hline
\end{tabular}

*See footnote table (2).

and selectivity of the cytotoxic effect on cancer cell rather than normal cells.

\section{Conclusion}

It could be concluded that liposomal systems in dispersion were employed for the delivery of sage phenolics via yoghurt. It was observed that stability of Sage phenolic extract (SPE) in yoghurt samples showed better results even during storage period of 15 days. To suggest the form of liposomal system to be used in liquid foods, physicochemical properties of such foods including $\mathrm{pH}$, zeta potential etc. will be crucial.

\section{Conflicts of interest}

No conflict of interest was reported by the authors.

\section{Formatting of funding sources}

None

\section{References}

[1] Sur S. and Panda C., Molecular aspects of cancer chemo-preventive and therapeutic efficacies of tea and tea polyphenols. Nutrition, 43, 8-15 (2017). doi: 10.1016/j.nut.2017.06.006.

[2] Neagu E., Paun G. and Radu, G. L., Chemical composition and antioxidant activity of Salvia officinalis concentrated by ultrafiltration. Romanian Biotechnological Letters, 19 (2), 9203 - 9211 (2014).

[3] Fang Z. and Bhandari B., Encapsulation of polyphenols- a review. Trends in food science and technology, $21 \quad(10), \quad 510-523 \quad$ (2010). doi.org/10.1016/j.tifs.2010.08.003

[4] Gibis M., Thellmann K., Thongkaew C. and Weiss J., Interaction of polyphenols and multilayered liposomal-encapsulated grape seed extract with native and heat-treated proteins. Food Hydrocolloids, 41, 119-131 (2014).

[5] Itsaranuwat P., Shal-Haddad K. and Robinson R. K., The potential therapeutic benefits of consuming 'health-promoting' fermented dairy products: a brief update. International Journal of
Dairy Technology, 56 (4), 203-210 (2003). doi:10.1046/j.1471-0307.2003.00106.x

[6] Brand-Williams W., Cuvelier M. E. and Berset C., Use of a free radical method to evaluate antioxidant activity. LWT - Food Science and Technology, $\mathbf{2 8}$ (1), 25-30 (1995). doi.org/10.1016/S0023-6438(95)80008-5

[7] Naczk M. and Shahidi, F., The effect of methanolammonia-water treatment on the content of phenolic acids of canola. Food Chemistry, 31 (2), 159-164 (1989). doi.org/10.1016/03088146(89)90026-5

[8] Djeridane A., Yousfi M., Nadjemi B., Boutassouna, D., Stocker P. and Vidal N., Antioxidant activity of some Algerian medicinal plants extracts containing phenolic compounds. Food Chemistry, 97 (4), 654-660 (2006). doi: 10.1016/j.foodchem.2005.04.028

[9] El-Messery T.M., El-Said M.M. and Farahat, E.S.A., Production of Functional Processed Cheese Supplemented with Nano-liposome of Mandarin Peel Extract. Pakistan Journal of Biological Sciences, 22 (5), 247-256 (2019). doi:10.3923/pjbs.2019.247.256

[10]El-Said M.M., El-Messery T.M. and El-Din, H.M.F., The encapsulation of powdered doum extract in liposome and its application in yoghurt. Acta Scientiarum Polonorum Technologia Alimentaria, 17 (3), 235-245 (2018). doi:10.17306/J.AFS.2018.0571

[11] Salama, H. H., Abd El-Salam M. H. and El-Sayed M.M., Preparation of $\beta$-carotene enriched nanoemulsion by spontaneous emulsification using oleic acid as nano carrier. Research Journal of Pharmaceutical, Biological and Chemical Sciences, 7 (4), 585 - 593 (2016).

[12] AOAC. Official methods of analysis, 19th ed. Association of Official Analytical Chemists, Washington (2012).

[13]Less G.J. and Jago, G.R., Method for the Estimation of acetaldehyde in culture dairy products. Australian Journal of Dairy Technology, 24-181 (1969).

[14] Salama, H. H., Abdelhamid S. M. and El Dairouty, R. K., Coconut bio-yogurt Phytochemical-Chemical and antimicrobialmicrobial activities. Pakistan Journal of Biological Sciences, 22 (11), 527-536 (2019). doi:10.3923/pjbs.2019.527.536

[15] NCCLS. National Committee for Clinical Laboratory Standards. Performance standards for antimicrobial susceptibility testing. 9th International Supplement. The Committee, Wayne. (NCCLS document no. M100-S9) (1999). 
[16] Harrigan, W. and McCance, M., Laboratory Methods in Food and Dairy Microbiology, 8th ed., Academic Press, London, UK (1990).

[17]FDA. Food and Drug Administration, 9th ed., Bacteriological Analytical Manual. AOAC International, Arlington, VA, USA (2002).

[18] Batran R. Z., Kassem A. F., Abbas E. M., Elseginy S. A. and Mounier M. M., Design, synthesis and molecular modeling of new 4phenylcoumarin derivatives as tubulin polymerization inhibitors targeting MCF-7 breast cancer cells. Bioorganic and Medicinal Chemistry, 26 (12), 3474-3490 (2018). doi: 10.1016/j.bmc.2018.05.022.

[19] Rastia M., Hatamipoura M.S., Aghamiria S.F. and Tavakoli M., Enhancement of domestic refrigerator's energy efficiency index using a hydrocarbon mixture refrigerant. Measurement, $45 \quad$ (7), 1807-1813 (2012). doi:10.1016/j.measurement.2012.04.002

[20] Ghorbanzade T., Jafari S.M., Akhavan S. and Hadavi, R., Nano-encapsulation of fish oil in nano-liposome and its application in fortification of yogurt. Food Chemistry, 216, 146-152 (2017). doi: 10.1016/j.foodchem.2016.08.022.

[21]Zhong J., Yang R., Cao X., Liu X. and Qin, X., Improved physicochemical properties of yogurt fortified with fish oil/-oryzanol by nano-emulsion technology. Molecules, 23 (1), 56 (2018). doi:10.3390/molecules23010056

[22] Tamime, A.Y. and Robinson, R.K., Yoghurt: Science and Technology, 1rd ed., Pergamon Press, Oxford (1985).

[23] Abd El-Aziz M., Ahmed N.S., Sayed A.F. Mahran G.A. and Hamad Y.A., In Proceedings of 9th Egyptian Conference for Dairy Science and Technology, October 9-11, Production of fat-free yoghurt using modified tapioca starch as fat replacer, pp 243 (2004).

[24] Dabija A., Codin`a G. G., Ropciuc S. G^atlan A. M. and Rusu, L., Assessment of the Antioxidant Activity and Quality Attributes of Yogurt Enhanced with Wild Herbs Extracts. Journal of Food Quality, 1-12 (2018). doi.org/10.1155/2018/5329386

[25] Liolios C.C., Gortzi O., lalas S., tsaknis J. and Chinou I., Liposomal incorporation of carvacrol and thymol isolated from the essential oil of Origanumdictamnus L. and in vitro antimicrobial activity. Food Chemistry, 112, 77-83 (2009). doi:10.1016/j.foodchem.2008.05.060

[26] Cantor S., Vargas L., Rojas O. E., Yarce C. J., Salamanca C. H. and Jose Oñate-Garzón J., Evaluation of the Antimicrobial Activity of Cationic Peptides Loaded in Surface-Modified Nanoliposome against Foodborne Bacteria. International Journal of Molecular Sciences, 20 (3), 680 (2019). doi:10.3390/ijms20030680.

[27] Behradmanesh S., Derees F. and Rafieian-kopaei M., Effect of Salvia officinalis on diabetic patients. Journal of Renal Injury Prevention, 2 (2), 51-54 (2013). doi: 10.12861/jrip.2013.18

[28] Noudoost B., Noori N., Gh A. A., Gandomi H., Basti A., Jebeli Javan J. and Ghadami F. Encapsulation of Green Tea Extract in Nanoliposome and Evaluation of its Antibacterial,
Antioxidant and Prebiotic Properties. Journal of Medicinal Plants, 14 (55), 1-13 (2015).

[29] Shori A. B. and Albloushi S., Antifungal Activity of Lactobacillus Plantarum and Sage Extract on Aspergillus Fumigatus in Yogurt. American Journal of Biomedical and Life Sciences, 6 (3), 3742 (2018). doi: 10.11648/j.ajbls.20180603.11

[30] El Batawy O.I. (2012). Production and properties of low-fat set yoghurt made with Jerusalem artichoke powder. Egyptian Journal of Food Science, 40, 77-90.

[31]Bisar G.H., ElSaadany K., Khattab A. and ElKholy W.M., Implementing maltodextrin, polydextrose and inulin in making a synbiotic fermented dairy product. British Microbiology Research Journal, 8 (5), 585-603 (2015). doi: 10.9734/BMRJ/2015/16950

[32] Salem M.M.E., Fathi F. A. and Awad, R. A., Production of probiotic ice cream. Polish Journal of Food and Nutrition Sciences, 55 (3), 267271(2005). 